\title{
MASTERING
}

\section{FRENCH 2}

France and the French 


\section{MACMLLAN MASTER SERIES}

\section{Banking}

Basic English Law

Basic Management

Biology

British Politics

Business Communication

Chemistry

COBOL Programming

Commerce

Computer Programming

Computers

Data Processing

Economics

Electrical Engineering

Electronics

English Grammar

English Language

English Literature

French 1

French 2

\author{
German \\ Hairdressing \\ Italian \\ Keyboarding \\ Marketing \\ Mathematics \\ Modern British History \\ Modern World History \\ Nutrition \\ Office Practice \\ Pascal Programming \\ Physics \\ Principles of Accounts \\ Social Welfare \\ Sociology \\ Spanish \\ Statistics \\ Study Skills \\ Typewriting Skills \\ Word Processing
}




\section{MASTERINLG}

\section{FRENGH 2}

\section{France and the French}

\section{E. J. NEATHER}

with the collaboration of

I. Rodrigues and M. Davis

\section{EDITORIAL CONSULTANT BETTY PARR}

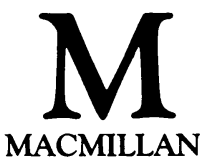


(c) E.J.Neather 1985

Illustrations @ Macmillan Education 1985

All rights reserved. No reproduction, copy or transmission of this publication may be made without written permission.

No paragraph of this publication may be reproduced, copied or transmitted save with written permission or in accordance with the provisions of the Copyright Act 1956 (as amended).

Any person who does any unauthorised act in relation to this publication may be liable to criminal prosecution and civil claims for damages.

First published 1985

Reprinted 1986

Published by

MACMILLAN EDUCATION LTD

Houndmills, Basingstoke, Hampshire RG21 2XS

and London

Companies and representatives

throughout the world

British Library Cataloguing in Publication Data

Neather, E. J.

Mastering French 2: France and the French.

- (Macmillan master series)

1. French language-Readers

I. Title

448.6'421 PC2117

ISBN 978-1-349-81222-6

DOI 10.1007/978-1-349-81220-2 


\section{CONTENTS}

Series editor's preface

Introduction: how to use this book

Acknowledgements

XV

TEACHING UNITS

\section{PART I LES FRANÇAIS}

1 Le Caractère Français

Le Français individualiste

Les clichés français

Pierre Daninos

Dialogue

J.-M. Macabrey

2 Les Français qui Consomment

Un si joli petit marché

J. Potherat

L'ère des grandes surfaces

K. Breen

Dialogue

3 Les Français qui Voyagent

S.N.C.F.: La voie royale

Le Nouvel Observateur

Les vacances

C. Rochefort

PROMENADES LITTÉRAIRES I

(1) Maximes

(2) La cigale et la fourmi

La Rochefoucauld

(3) Arrias

La Fontaine

(4) II faut cultiver notre jardin

La Bruyère

(5) Au bord du lac

Voltaire

Rousseau

\section{PART II LA FRANCE}

4 Le pays de France

La France à vol d'oiseau

F. Duhamel

Une certaine idée de la France

C. de Gaulle

Dialogue

5 La Ville de Paris

La découverte de Paris

M. Aymé and J.-P. Clébert

Le centre Pompidou

I. Zaknič

Le quartier latin

A. Maurois 
6 La France Administrative

La bureaucratie française

F. Kupferman

Les Français jugent l'État

L'Express

Le peuple souverain

M. Cardoze

Dialogue

PROMENADES LITTÉRAIRES ॥

(1) En Touraine

H. de Balzac

(2) Un mariage normand

G. Flaubert

(3) Le maquis corse

P. Mérimée

(4) Chanson de la Seine

J. Prévert

(5) Je vous salue ma France

Aragon

PART III SOCIÉTÉ FRANÇAISE

7 La Famille

Sacrées familles

S. O'DY

Les grands-parents retrouvés

L. Delwasse

Dialogue

8 Jeunes et Vieux

129

Une politique de vieillesse

S. de Beauvoir

Les jeunes: marre de la politique

N.-J. Bréhon

9 Les Femmes

La femme dans la société française

Objections au féminisme

C. Chombeau

Écrire un ouvrage féministe

M. Yourcenar

Dialogue

B. Groult

10 L'Enseignement

Partout où il y a un champ, qu'il y ait un livre

V. Hugo

Les collèges à I'heure de la réforme

C. Sacase

Le classement des universités

E. Fallot

Dialogue
(1) Le rentrée scolaire
M. Pagnol
(2) Une enfance heureuse
J.-P. Sartre
(3) Le cancre
J. Prévert
(4) Le sentiment de l'absurde
A. Camus 


\section{PART IV CULTURE FRANÇAISE}

11 La Chanson Française

La chanson folklorique

J. Canteloube

Hommage au gorille

L. Rioux

12 Les Médias

Autant de lecteurs, autant de

journaux

M. Blondel

Presse - une loi de trop

Y. Cuau

Radio - vers la décentralisation

Journal de l'Année

13 La Cuisine Française

Le code de la bonne chère

E. de Pomiane

La nouvelle cuisine

C. Fischler

14 La Langue Contemporaine

Parler en nouveau français

R. Beauvais

We all speak Frenglish

W. Lewis

\section{REFERENCE MATERIAL}

Key to Exercises

Guide to Pronunciation

Grammar Reference Section

Index to Grammar Section

Bibliography 


\section{SERIES EDITOR'S PREFACE}

Mastering French 2, the second French book in the Master Series, is intended for students working, without a teacher, to extend their command of spoken and written French and to learn more about France and her people. When Mastering French was published in 1982, the course was described as 'a carefully planned introduction to the language and a secure foundation for further study', for which it was hoped that the Master Series would 'ultimately give additional help'. The present publication fulfils that undertaking and will surely be warmly welcomed by the many thousands who have studied Mastering French and the countless others who have acquired by other means a good basic knowledge of the language and need a stimulating and well organised programme to support more advanced work.

In the first book, the main emphasis was placed on understanding and using the spoken language, although reading and writing were not neglected. In Mastering French 2, the sensitive appreciation, the ready comprehension and the use of written French are the principal objectives, although listening and responding to the language as it is spoken today are important elements in the course. A glance at the list of contents gives a hint of its many individual features. It is an anthology with a difference. An imaginatively chosen selection of authentic passages from contemporary sources gives an insight into various aspects of life in present-day France. Some of these form the topics of discussion by native speakers, whose recorded conversations provide a further source of information and opinion and an excellent demonstration of the language as spoken by educated and cultivated French people. Another series of extracts from the poetry and prose of earlier writers recaptures past traditions in a way that illuminates the present. These delightful excursions into the past are aptly named Promenades Littéraires.

The author's helpful comments on each extract are followed by explanations of more unusual words and phrases, and by reference to some of the grammatical features exemplified in the chosen passages or dialogues; the inclusion of the latter ensures that the idiosyncrasies of spoken French are taken into account. The contemporary extracts and the associated conversations are followed by exercises, grouped in two sections. The first is devised to lead to a clearer understanding of the passage; the second gives practice in using the language within that context. No exercises are associated with the Promenades Litteraires. 
A Reference Section gives a key to the exercises, and a guide to pronunciation, which contains an intriguing selection of traditional rhymes and jingles for use as an entertaining and helpful form of oral practice. A major item in this Section is a comprehensive and comprehensible Grammar Reference, with its own list of contents and index. A distinctive feature is the ingenious integration of the grammatical explanations with the chosen passages, so that grammar is learnt in the context of familiar material, not in the isolation of unfamiliar theory. A cassette, an integral part of the programme, contains all the dialogues and selected exercises, parts of the pronunciation guide and some of the literary extracts.

The author has given in his introduction a clear analysis of the aims and objectives of the publication and suggested ways of using it effectively. The student is advised to read this section carefully before embarking on this exciting anthology, which will surely chart the course for a rewarding and diverting voyage of discovery of the French language, of France and her people.

BETTY PARR

Editorial Consultant 


\section{INTRODUCTION:}

\section{HOW TOUSE THISBOOK}

Mastering French 2 is intended for students who already have a working knowledge of French, either dating back to their schooldays, or acquired more recently at evening classes, from $\mathrm{BBC}$ programmes, or by studying a book such as the first volume of Mastering French.

\section{GENERAL AIMS}

For these students the book has two main aims:

1. To offer students the chance to familiarise themselves with the contemporary French language as expressed in a wide range of written texts and spoken dialogues.

2. To gain some knowledge of the heritage of French language and culture by an introduction to selected reading passages from literary works.

Of course, a book of this size cannot hope to be complete in its coverage, and there have been difficult choices to make, both in selecting the topics which form the framework for the chapters, and in choosing texts to illustrate these topics. Without making any impossible claims, the author believes that the final choice, both of topics and texts, provides a balance of content and style which will enable students to make significant strides in their mastery of the language.

\section{LANGUAGE TEACHING OBJECTIVES}

Within the two main aims expressed above the book pursues certain specific objectives in developing students' language skills:

1. The development of reading skills by extending recognition and understanding of vocabulary and structures within a range of topics.

2. The development of listening skills by the use of recordings of readings and dialogues related to the same range of topics. 


\section{INTRODUCTION}

3. The development of speaking skills in exercises involving the use of language read in the texts and heard in the dialogues.

4. The development of writing skills within certain limited fields, such as letter writing.

For a course-book such as this, aimed at the individual learner, the first two objectives above are the prime concern, since the students' chances to encounter the more difficult stages of the language are perhaps more frequent through the written word of books and magazines and the spoken word of the radio.

\section{CULTURAL OBJECTIVES}

It is not possible to use language, whether reading, listening, speaking or writing, unless one uses it for something. At an elementary level, one may be satisfied with basic communication, but beyond that, any encounter with the language is an encounter with the culture of the language and with the people who speak it. All the texts in this book are authentic, that is to say they are written or spoken by French people, and not concocted only for a textbook. So all the extracts convey something about France and the French, whether in the contemporary context, as in the topics, or with a more historical point of view, as in the Promenades Litterraires. Getting to know a different culture is closely bound up with the study of language, but it is not something which can be quickly acquired, by means of a single book. The author hopes only that the student will feel better informed and knowledgeable at the end of this book, and anxious to find out more. The study of foreign languages breeds an undying curiosity about other ways and other countries.

\section{LEVELS OF DIFFICULTY AND THE USE OF THIS BOOK}

In using authentic materials, written and spoken, such as are found in a book of this kind, it is not always possible to grade the texts according to levels of difficulty. Students should not, therefore, expect the texts to start easy and grow gradually more difficult, though the type of exercises associated with the texts may become more demanding as the book progresses. Depending on the students' present level of competence in the language, some of the texts may, at first, seem a little daunting and difficult, but it is important not to be put off by unknown vocabulary, and to understand as much as possible without necessarily knowing every word. The exercises are devised to assist this initial understanding. 
Each chapter is organised as follows, as an aid to working with the materials:

\section{Reading passage}

2. Exercises - Section $A$ These are exercises designed to help understanding and to develop methods of coping with new materials in the foreign language. The suggestion is that students should attempt these exercises before studying the vocabulary and grammatical explanations, so as to develop the capacity to guess at the meaning of words in context and appreciate the internal pattern of organisation of a text.

3. Explanations This section consists of a select vocabulary, a list of expressions and idioms which may be new to the reader, and a note of the grammatical items which should be consulted in the grammar reference section in order to tackle the exercises in Section B. Of course, any authentic text will contain so many grammatical elements that it would be a lengthy business to study them all. A selection is therefore made to provide practice in particular points of which the text gives a number of examples.

4. Exercises-Section $B$ These are exercises which concern themselves with practising the specific grammatical points selected from the text.

This same sequence is followed for a second reading text, chosen to contrast with the first passage, although concerned with the same general topic area. There then follows, in seven of the chapters, a recorded dialogue, with exercises in listening comprehension and suggestions for developing speaking skills and powers of expression.

The author does not imagine that all students will wish to start at page 1 and work methodically through the book, though some will prefer to work in this way. Others might wish to choose certain topics which interest them first. Or some might decide to work more intensively on reading skills, concentrating on the passages and on the Section A exercises, and omitting, on the first reading, Section B and the dialogues. The book offers a resource and students will develop their own ways of drawing on the range of materials offered.

\section{PROMENADES LITTÉRAIRES}

Concern for the contemporary language need not leave out of account the language of previous periods; indeed, it could well be argued that a full understanding of the present situation requires some knowledge of the linguistic heritage. Each of the three sections entitled Promenades Littéraires is loosely tied-in with the topic of the preceding group of chapters, and offers a necessarily limited choice of passages from significant figures of French literature, firstly from the seventeenth and eighteenth centuries, 


\section{INTRODUCTION}

then from the nineteenth century, and finally from our own century. No exercises are associated with these extracts. A short vocabulary is given, to help with any particular difficulties, otherwise the presence of these passages serves as a further range of reading material, to be tackled by the student at any appropriate stage, or in association with the topics being studied.

\section{CASSETTE}

The cassette which accompanies this book contains recordings of all the dialogues, readings of a selection of the poems and passages in the Promenades Litteraires, and the examples in the Pronunciation Guide. Items which are recorded on cassette are shown in the book by the symbol

\section{REFERENCE SECTIONS}

The Reference Sections of the book contain:

1. A key to all exercises.

2. A guide to pronunciation which is more extensive and detailed than that given in Mastering French 1.

3. A Grammar Reference Section. Although a summary of grammar of this kind cannot be complete, care has been taken to refer to all the points specifically raised in the Section B exercises, and also to cover a wide range of other queries which might rise in students' minds on reading the passages. The point must be made here that a more advanced book of this kind will inevitably raise many points of vocabulary and grammar which cannot all be dealt with in the limited space available. It is therefore suggested that all students should have a good dictionary to work with, and possibly also a more comprehensive grammar than can be provided here.

4. A bibliography suggesting dictionaries, grammars and other sources of further study and reading.

E. J. NEATHER 


\section{ACKNOWLEDGEMENTS}

For the presentation of this book, my sincere thanks are due, in particular, to the series editor, Betty Parr, who has played no small part in shaping its final form. Thanks go also to my two collaborators, Isabelle Rodrigues and Madeleine Davis, who participated in the project from start to finish, contributing their knowledge, experience and skills. To my wife Elisabeth go my special thanks for her unfailing support in this and all my other undertakings.

E. J. N.

The author and publishers wish to thank the following who have kindly given permission for the use of copyright material: Editions du Centurion, Durand S.A. Editions Musicales, L'Express, Librarie Ernest Flammarion, Editions Gallimard, Editions Bernard Grasset, Hachette, Hachette, Littérature, Editions Julliard, Larousse, Marie-Claire Album, Marie France, Messidor, Editions Albin Michel, Le Monde, Fernand Nathan Editeur, Le Nouvel Observateur, Librairie Plon.

The author and publishers wish to acknowledge, with thanks, the following photographic sources: Agence France-Presse, Documentation Française Photothèque, Editions Denoël, French Government Tourist Office.

Every effort has been made to trace all the copyright holders but if any have bean inadvertently overlooked the publishers will be pleased to make the necessary arrangements at the first opportunity. 


\section{TEACHING UNITS}

